\title{
Main Driving Factors for Seacoast Vegetation in the Southern and Eastern Baltic
}

\author{
Piotr Hulisz $^{1}$ - Agnieszka Piernik ${ }^{2}$ - Jasmin Mantilla-Contreras ${ }^{3}$ - Tiina Elvisto ${ }^{4}$
}

Received: 1 December 2015 / Accepted: 21 July 2016 / Published online: 17 August 2016

(C) The Author(s) 2016. This article is published with open access at Springerlink.com

\begin{abstract}
This study aimed to determine the role of environmental factors in the pattern of vegetation related to marsh soils, which are rare in the Baltic coastal zone. It was assumed that the pattern of vegetation directly affected by seawater depends on seawater salinity, and in general reflects the decreasing salinity gradient of the Baltic Sea. The research of vegetation and soils $(0-25 \mathrm{~cm})$ has been undertaken on 11 selected sites along the Baltic seacoast in Germany, Poland and Estonia. According to TWINSPAN classification, five plant communities were distinguished: the Puccinellia maritima-Spergularia marina community, Juncus gerardi community, Agrostis stolonifera-Phragmites australisScirpus lacustris ssp. tabernaemontani community, Phragmites australis-Calystegia sepium community and Elymus repens community. A canonical correspondence analysis showed that the most important environmental factors influencing vegetation differentiation were: electrical conductivity of the saturation paste extract, hay/pasture management, redox potential, soil moisture and actual $\mathrm{pH}$. In conclusion, the spatial distribution of the investigated vegetation and soil properties along the Baltic Sea shore were inconsistent with
\end{abstract}

Agnieszka Piernik

piernik@umk.pl

1 Faculty of Earth Sciences, Nicolaus Copernicus University, ul Lwowska 1, 87-100 Torun, Poland

2 Faculty of Biology and Environment Protection, Nicolaus Copernicus University, ul Lwowska 1, 87-100 Torun, Poland

3 Institute for Biology and Chemistry, University of Hildesheim, Universitätsplatz 1, 31141 Hildesheim, Germany

4 School of Natural Sciences and Health, Tallinn University, 25 Narva Rd, 10120 Tallinn, Estonia the spatial salinity gradient of the open surface seawater, but was significantly dependent on local conditions. This was confirmed by the highest soil salinity and most abundant occurrence of Salicornia europaea in Estonia.

Keywords CCA · Coastal meadows · Coastal marsh soils · Gradient analysis $\cdot$ Halophytes $\cdot$ Soil salinity

\section{Introduction}

The Baltic Sea is a brackish, semi-enclosed, almost non-tidal, inland water body in Northern Europe. Due to limited water exchange with the North Sea and its receiving a large freshwater runoff, there is a strong, west-to-east salinity gradient across the open Baltic surface seawater $(0-10 \mathrm{~m})(20 \%$ in the Kattegat; $8.0 \%$ in the Bay of Greifswald, $7.0 \%$ in the Gulf of Gdańsk, about $5.5 \%$ in northern Estonia, in the Gulf of Bothnia and less than $3 \%$ in the eastern part of the Gulf of Finland). Fluctuations in seawater salinity are low during the year, with the maximum usually recorded in the spring and summer periods due to inflow from melting ice, river water and precipitation (Majewski and Lauer 1994).

The coastal vegetation reflects plant species' tolerance to salinity and waterlogging, which is visible in their zonation (Chapman 1960; Adam 1990). Therefore, besides salinity, the dominant factor for Baltic coastal vegetation is water level fluctuations, which are dependent on the season, and determined by wind direction and force, air pressure and discharge from rivers (Dijkema 1990), as well as microtidal activity (Adam 1990). Another very important factor seems to be rises in sea level, which may result in the loss of coastal habitats (Nicholls et al. 1999). Some authors (i.a., Morris et al. 2002; Moeslund et al. 2011) emphasise that the Baltic coastal areas are highly susceptible to this global change because the tidal 
influence is negligible. On the other hand, for some northern and eastern Baltic regions the sea-level rise can be counteracted by ongoing postglacial land uplift (Kall et al. 2014).

The Baltic coastal marsh vegetation can be generalised as salt grasslands (managed habitats) and brackish reed beds (natural vegetation). Salt grasslands comprise areas that have developed due to sedimentation, peat formation or land rise, and are irregularly flooded by saline or brackish water (Wanner 2009). However, some of them on the Baltic coast are affected not only by seawater but also by brine associated with fossil salt deposits uplifted to the surface, or relict seawater (Grube 2000; Bosiacka et al. 2011). They are characterised by relatively high salinity and a high number of halophytic plant species (Piotrowska 1974; Bosiacka et al. 2011). Moreover, salt grasslands are found at a higher level in the zonation, and more inland on so-called salt patches, which developed as a result of chloride and sulphate accumulation in the topsoils during dry periods (Dijkema 1990).

In general, Baltic salt grasslands are considered to be valuable and endangered ecosystems (Dijkema 1990; Rannap et al. 2007; Wanner 2009; Bosiacka et al. 2016). They are designated as wetlands of international importance according to the Ramsar Convention on Wetlands (1971), as habitats of European importance according to the EU habitat directive (European Commission 1992) and as special protection areas for birds according to the EU birds directive (European Commission 1979).

The Baltic Sea coast is dominated, especially in Poland, by sandy beaches, dunes or cliffs. Although small, there are many salt marsh sites with brackish or salt marsh soils, which have developed under the direct influence of open Baltic water or brackish water in river deltas and lagoons (Hulisz 2013). They have formed on both marine and marine-alluvial sediments. The properties of these soils are mostly dependent on local water properties and flooding frequency. Such salt marsh sites have been described in Germany (Bernhardt and Koch 2003), Sweden (van der Graaf et al. 2007), Estonia (Ratas et al. 2006; Hulisz et al. 2011) and Poland (Pracz 1989; Hulisz 2013; Hulisz 2016). The spatial differentiation of vegetation directly related to marsh soil properties, had not been well described until now, whereas the general characteristics of the Baltic coastal grasslands have (Rebassoo 1975; Dijkema 1990; Fock et al. 2002; Czyż 2006; Wanner 2009; Ludewig et al. 2015).

Therefore, the aim of our study was to determine the role of environmental factors in the pattern of vegetation related to brackish/salt marsh soils along the southern and eastern Baltic seashore. It was assumed that this pattern depends on water salinity, and in general reflects the decreasing salinity gradient across the Baltic Sea. Moreover, we tested if field measurements of actual soil properties reflect vegetation differentiation and could be included in simple monitoring of these valuable habitats.

\section{Study Area}

The research was carried out in four study areas along the coastal zone of the southern and eastern Baltic Sea Coast: Bay of Greifswald, Germany (G); Szczecin Lagoon, Poland (PS); Gulf of Gdańsk, Poland (PG) and the western and northern coast of Estonia (E) - Fig. 1.

The Bay of Greifswald is a lagoon located in north-eastern Germany, and locally called "Greifswalder Bodden". There are flat plains of glacial origin built from sand and tills, and local depressions filled with organic deposits (Niedermeyer et al. 1995). The study was conducted at two sites seasonally flooded with seawater: Karrendorfer Wiesen and Kooser Wiesen. They are managed, and grazed by livestock (cattle). In contrast to the Karrendorfer Wiesen, revitalised after removal of flood embankments, the Kooser Wiesen have never been diked and have been preserved as nearly-natural, undisturbed salt grasslands (Lampe and Janke 2004).

The Szczecin Lagoon is a large, brackish water body (salinity $0.6-0.9 \%$ ) in Germany and Poland. It constitutes the Oder River estuary system, and is affected by seawater intrusions (backwater) through the Peenestrom, Świna and Dziwna straits. The first site is situated within the reverse delta of the Świna River (Karsiborska Kępa Island), whereas the two others (Chrzaszczewo Island, Wrzosowo) are located on the banks of the Dziwna strait. The PS study sites were dominated by peat, mud and silty alluvial soils, and used as a pasture in some places. Karsiborska Kępa Island ( 315 ha) was diked and turned into a polder during the first half of the twentieth century. Chrzaszczewo Island $\left(10 \mathrm{~km}^{2}\right)$ is partially protected against flooding by embankments.

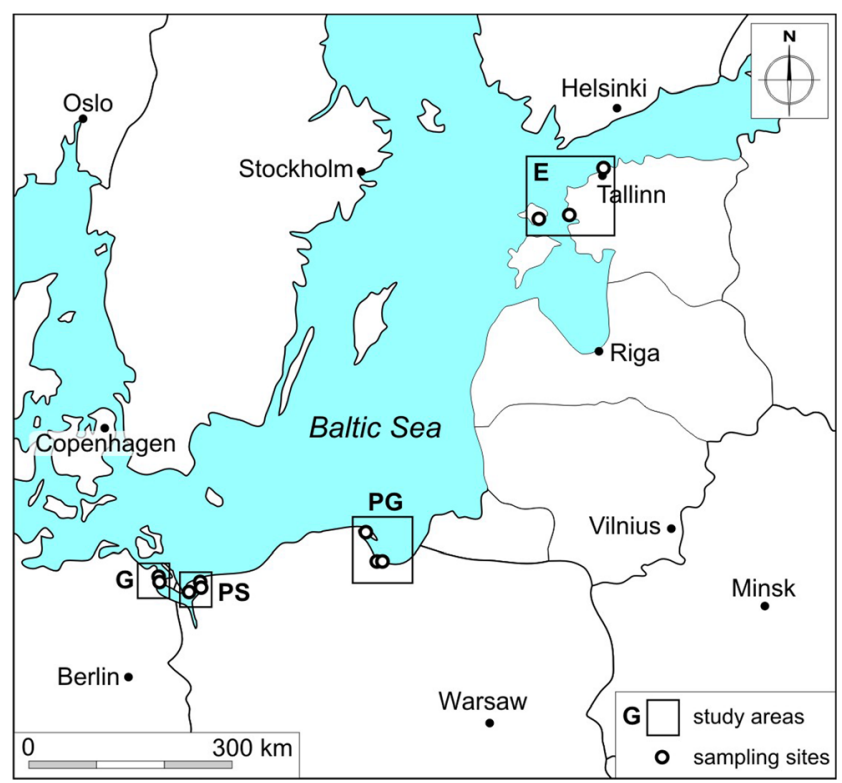

Fig. 1 Location of the study areas and the sampling sites: G - Germany; PS - Poland, Szczecin Lagoon; PG - Poland, Gulf of Gdańsk; E - Estonia 
The Gulf of Gdańsk is located in northern Poland. The Władysławowo site is situated in the coastal zone of the Puck Lagoon on the Hel Peninsula, the long sandy spit that constitutes a border with the open Baltic waters. The other sites were located within the Vistula River delta, and therefore strongly affected by backwater. Soils of the PG study area were developed from stratified, organic-matter-rich, marine and alluvial deposits, which reflect the changing conditions of sedimentation often caused by human impact. This is particularly evident in the Vistula River delta, where the land was drained and the river banks were strengthened (Hulisz 2013). At present the Władysławowo site is used as pasture, while the others are wasteland.

Three study sites are on the Estonian sea coast (E). Two of them were located in the north-west (Kassari Island) and eastern (Põgari-Sassi) sections of the Väinameri Strait. They are on the shores of shallow lagoons, with low land relief and mineral soils formed of bipartite marine sediment deposits overlaying weakly-permeable, carbonate-rich glacial sediments (Hulisz et al. 2011; Hulisz 2013). These sites are traditionally grazed meadows. The third study site (Paljassaare) is in the eastern part of the Saartevahe Haak, a small bay at the tip of the Paljassaare peninsula in the Tallinn area on the Gulf of Finland. Overgrown with reed beds, it is a sandy beach zone with a marine sand layer, resulting from accumulating wave activity, which sits on till layers (Elvisto 2010). This site is not managed.

Most study sites have a protected status (e.g. a halophyte reserve in Władysławowo, Käina Bay-Kassari Landscape Protection Area and Matsalu National Park), and were included in the Natura 2000 network. Some are also a refuge for rare bird species (e.g. Karsiborska Kępa Island, the Vistula River delta and Paljassaare) listed in the EU birds directive (European Commission 1979).

In the Bay of Greifswald area, similarly to the Polish coast, the climate is warm temperate, fully humid with warm summer $(\mathrm{Cfb})$. The climate of Estonian coast is significantly colder, and classified as snow, fully humid with moderately warm summer (Dfb) (Kottek et al. 2006). The changes in seawater level in the study areas are wind-induced and partly depend on the varying seasonal atmospheric pressure. According to Majewski and Lauer (1994), extreme deviations from the mean sea level are usually recorded during the autumn and winter months. They range respectively from +0.95 to $1.0 \mathrm{~m}(\mathrm{G})$, from +1.1 to $0.7 \mathrm{~m}$ (PS), from +1.5 to $1.0 \mathrm{~m}$ (PG) and from +1.2 to $0.9 \mathrm{~m}(\mathrm{E})$.

\section{Methods}

\section{Field Work}

In total, 39 phytosociological relevés were collected in patches directly affected by seawater: 6 in Germany (G1-G2 -
Karendorfer Wiesen, G3-G6 - Kooser Wiesen), 23 in Poland (PS1-PS11 - Karsiborska Kępa Island, PS12-PS13 - Chrząszczewo Island, PS14-PS15 - Wrzosowo, PG1 Sobieszewo Island, PG2-PG7 - Władysławowo, PG8 Brave Vistula River outlet), and 10 in Estonia (E1-E5 Kassari Island, E6-E8 - Põgari-Sassi, E9-E10 - Paljassaare) - Fig. 1. Relevés were taken along a gradient from the waterline, i.e. from the pioneer zone to the meadow or reed beds usually 2-3 points. The Braun-Blanquet method was used (Braun-Blanquet 1964; Westhoff and van der Maarel 1978). The size of each relevé was ca. $10 \mathrm{~m}^{2}$ to represent local soil conditions. Nomenclature follows Flora Europaea (Tutin et al. 1964-1980). In each plot a soil sample (0-25 cm) was taken. Three random samples were taken by sampler in each plot and mixed to create one representative for the relevé. The following soil properties related to current environmental conditions were measured in the field: redox potential $\left(\mathrm{E}_{\mathrm{h}}\right)$ and reaction $\left(\mathrm{pH}_{\mathrm{a}}\right)$ by potentiometric method, electrical conductivity $\left(\mathrm{EC}_{\mathrm{a}}\right)$ and moisture content ( $\% v / v)$ of bulk soil (M) by Time Domain Reflectrometry (TDR). In addition to soil material, 28 Baltic Sea water samples, representative for each of the four study areas, were taken and analysed. As far as possible, each plot was classified within categories of management type: (i) not used lands (salt meadows excluded from exploitation) and (ii) hay/pasture lands (managed salt meadows).

\section{Laboratory Analysis}

In the air-dry soil samples, the organic matter (OM) content was determined by loss on ignition at $550{ }^{\circ} \mathrm{C}$. Saturated paste extracts were prepared to evaluate soil salinity level. Reaction $\left(\mathrm{pH}_{\mathrm{e}}\right)$, electrical conductivity $\left(\mathrm{EC}_{\mathrm{e}}\right)$, content of chlorides $(\mathrm{Cl})$, sodium $\left(\mathrm{Na}^{+}\right)$, calcium $\left(\mathrm{Ca}^{2+}\right)$ and magnesium $\left(\mathrm{Mg}^{2+}\right)$ ions were determined (van Reeuwijk 2006). In addition, reference measurements ( $\mathrm{pH}, \mathrm{EC}$ and ionic composition) were taken in the seawater (Hermanowicz et al. 1999). Based on the obtained results, the following calculations were made (Jackson 1958; van Reeuwijk 2006): sodium adsorption ratio (SAR), salt percentage in saturation extract $\left(\mathrm{P}_{\mathrm{ew}}\right)$ and salt percentage in soil $\left(\mathrm{P}_{\mathrm{es}}\right)$.

\section{Data Analysis}

The influence of location (G, PS, PG and E study areas) on soil properties was tested by Kruskal-Wallis one-way analysis of variance by ranks with post-hoc mean rank multiple comparison (Dunn test) (Zar 1999). Box-and-whisker plots were drawn using STATISTICA 9.0 software (Statsoft Inc.).

Before the analysis of species data, the cover/abundance values obtained with the Braun-Blanquet scale were transformed into ordinal scale values according to van der Maarel (1979).

Plant communities were separated from the set of phytosociological relevés by the Two Way Indicator Species Analysis (TWINSPAN, Hill 1979) with the use of the TWINSPAN 
package (Hill and Šmilauer 2005). They were defined as groups of similar species composition and abundance.

The pattern of vegetation distribution in the gradient of measured environmental variables was analysed by ordination methods. Canonical Correspondence Analysis was applied (CCA) because Detrended Correspondence Analysis (DCA) results detected a strong unimodal structure in the vegetation data (Jongman et al. 1995). The relative importance of each environmental variable and its statistical significance in vegetation differentiation was assessed by the forward selection of the explanatory variables and Monte Carlo permutation test. The independent and dependent effect of each factor was taken into account. The Canoco 5.0 package was used for calculations (ter Braak and Šmilauer 2012).

For comparison of soil parameters between distinguished plant communities, the same nonparametric tests were used as in the case of research area comparisons (Kruskal-Wallis oneway analysis of variance by ranks with post-hoc Dunn test) (Zar 1999).

\section{Results}

\section{Water and Soil Properties}

The coastal seawater was characterised by typical brackish features ( $\mathrm{pH}$ 7.6-9.0; EC $8.0-11.1 \mathrm{dS} \cdot \mathrm{m}^{1}$; salinity $4.7-$ $7.0 \%$ ) - Table 1. Although the samples were taken in different

Table 1 Ranges of selected properties of the Baltic coastal seawater in the studied areas $(2009-2011 ; n=28)$

\begin{tabular}{llllll}
\hline Parameter & & $\mathrm{G}$ & $\mathrm{PS}$ & $\mathrm{PG}$ & $\mathrm{E}$ \\
\hline $\mathrm{pH}$ & Min & 8.1 & 7.9 & 7.6 & 8.3 \\
& Max & 8.6 & 8.4 & 8.7 & 9.0 \\
$\mathrm{EC}\left[\mathrm{dS} \cdot \mathrm{m}^{-1}\right]$ & Min & 8.2 & 9.2 & 8.0 & 9.5 \\
& Max & 10.8 & 10.6 & 11.1 & 11.1 \\
$\mathrm{Salinity}[\% \mathrm{o}]$ & Min & 5.0 & 5.1 & 4.7 & 5.8 \\
& Max & 5.5 & 5.5 & 6.8 & 7.0 \\
$\mathrm{HCO}_{3}^{-}\left[\mathrm{g} \cdot \mathrm{dm}^{-3}\right]$ & Min & 0.14 & 0.11 & 0.14 & 0.08 \\
& Max & 0.23 & 0.13 & 0.17 & 0.14 \\
$\mathrm{SO}_{4}{ }^{2-}\left[\mathrm{g} \cdot \mathrm{dm}^{-3}\right]$ & Min & 0.38 & 0.26 & 0.41 & 0.43 \\
& Max & 0.47 & 0.40 & 0.56 & 0.55 \\
$\mathrm{Cl}^{-}\left[\mathrm{g} \cdot \mathrm{dm}^{-3}\right]$ & Min & 2.79 & 2.84 & 2.58 & 3.23 \\
& Max & 3.07 & 3.06 & 3.76 & 3.88 \\
$\mathrm{Na}^{+}\left[\mathrm{g} \cdot \mathrm{dm}^{-3}\right]$ & Min & 1.21 & 1.46 & 1.02 & 1.80 \\
& Max & 1.72 & 1.83 & 2.25 & 2.43 \\
$\mathrm{Ca}^{2+}\left[\mathrm{g} \cdot \mathrm{dm}^{-3}\right]$ & Min & 0.11 & 0.08 & 0.07 & 0.09 \\
& Max & 0.12 & 0.09 & 0.10 & 0.18 \\
$\mathrm{Mg}^{2+}\left[\mathrm{g} \cdot \mathrm{dm}^{-3}\right]$ & Min & 0.21 & 0.17 & 0.17 & 0.19 \\
& Max & 0.39 & 0.22 & 0.23 & 0.21 \\
\hline
\end{tabular}

geographical locations, a relatively low spatial variability of seawater properties was observed. However, the highest $\mathrm{pH}$, $\mathrm{EC}$ values and $\mathrm{Na}^{+}, \mathrm{Cl}, \mathrm{SO}_{4}{ }^{2}$ ion content were recorded in the coastal waters in northern Poland (PG) and Estonia (E). Two hydrochemical types of water are distinguished: $\mathrm{Cl}-\mathrm{Na}$ (PS, $\mathrm{PG}, \mathrm{E})$ and $\mathrm{Cl}-\mathrm{Na}-\mathrm{Mg}(\mathrm{G})$. The latter contained up to six times more magnesium than calcium.

The characteristics of the investigated soils is shown in Fig. 2. They were formed on stratified marine-alluvial and marine deposits dominated by sands with varying admixtures of finer fractions. Many of these soils had thick surface horizons (up to $30 \mathrm{~cm}$ ), rich in both autochthonous and allochthonous organic matter.

The Kruskal-Wallis test with post-hoc mean rank multiple comparison revealed that most of the analysed soil parameters (with the exception of $\mathrm{Mg}^{2+}$ and $\mathrm{P}_{\mathrm{es}}$ ) significantly differed between the study areas. The salt percentage $\left(\mathrm{P}_{\mathrm{sw}}\right)$, and major constituents of seawater such as $\mathrm{Cl}$, $\mathrm{Na}^{+}, \mathrm{Ca}^{2+}$ ions were excluded from the diagram because these parameters demonstrated a strong correlation with such salinity indices as $\mathrm{EC}_{\mathrm{e}}$ and SAR.

The actual moisture $(\mathrm{M})$ and organic matter $(\mathrm{OM})$ content in all analysed soil samples was very heterogeneous (M 9$78 \%$, OM $0.3-56 \%$ ). The first parameter was significantly higher $(p=0.043)$ in soils from study area $\mathrm{G}$ than in study area $\mathrm{E}$, while the second was significantly lower in $\mathrm{E}$ than in other regions ( $p=0.010,0.014$ and 0.033 , respectively). The studied soils had a redox potential $\left(\mathrm{E}_{\mathrm{h}}\right)$ in the range of 25 to $517 \mathrm{mV}$, which suggests the presence of both anaerobic conditions and strong oxidation of the soil environment. The $E_{h}$ values recorded in soils from the PG study area were significantly lower (0.043) than in soils from G (Fig. 2).

The values of $\mathrm{pH}_{\mathrm{a}}$ varied from 4.1 to 7.6 , and $\mathrm{pH}_{\mathrm{e}}$ from 2.2 to 8.1. The strong acid reaction $\left(\mathrm{pH}_{\mathrm{e}}\right)$ was measured in ironsulphide-rich and carbonate-poor soil samples (G and PS), which were oxidised under laboratory conditions. This may suggest the presence of potential acid sulphate soil material. The $\mathrm{pH}_{\mathrm{a}}$ and $\mathrm{pH}_{\mathrm{e}}$ parameters showed a similar pattern, and were significantly lower in regions $\mathrm{G}(p=0.000$ and 0.008$)$ and PS ( $p=0.002$ and 0.004$)$, as compared to region $\mathrm{E}$.

Electrical conductivity $\left(\mathrm{EC}_{\mathrm{a}} 2.4-9.0 \mathrm{dS} \cdot \mathrm{m}^{1} ; \mathrm{EC}_{\mathrm{e}} 12-48 \mathrm{dS}\right.$. $\mathrm{m}^{1}$ ) and sodium adsorption ratio (SAR 16-36) reached significantly higher maximum values in study area $\mathrm{E}$ than in study area PS ( $p=0.008,0.028$ and 0.012 , respectively) - Fig. 2 .

\section{Vegetation of Seashore Zone}

In total, 93 species were noted in the relevés. The most frequent species from the whole study area were: Agrostis stolonifera (present in $64 \%$ of relevés), Atriplex hastata var. salina (54\%), Spergularia marina (44\%), Phragmites australis (41\%) and Juncus gerardi (38\%). Among halophytes, the most frequent besides A. prostrata, S. marina 

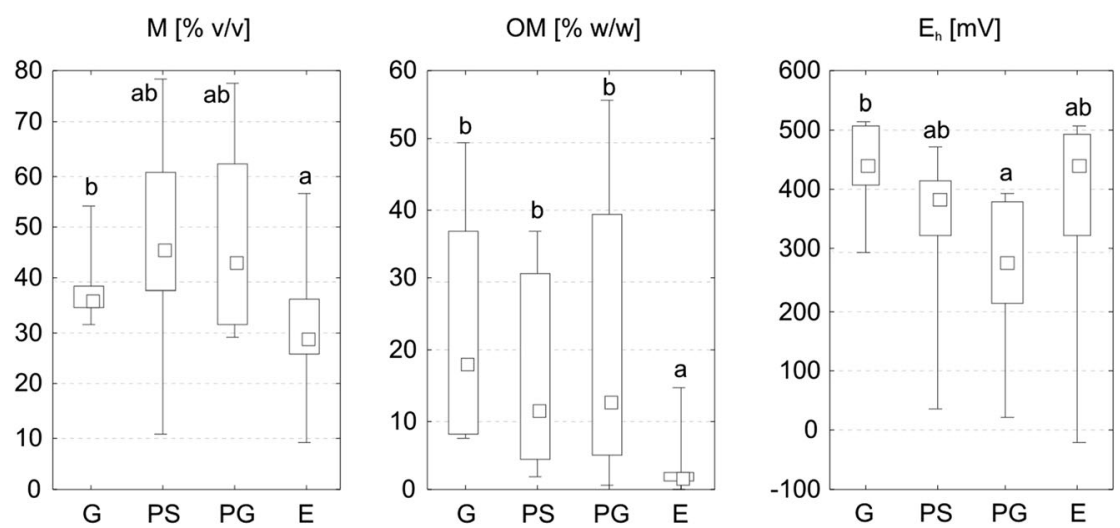

$\mathrm{pH}_{\mathrm{a}}$
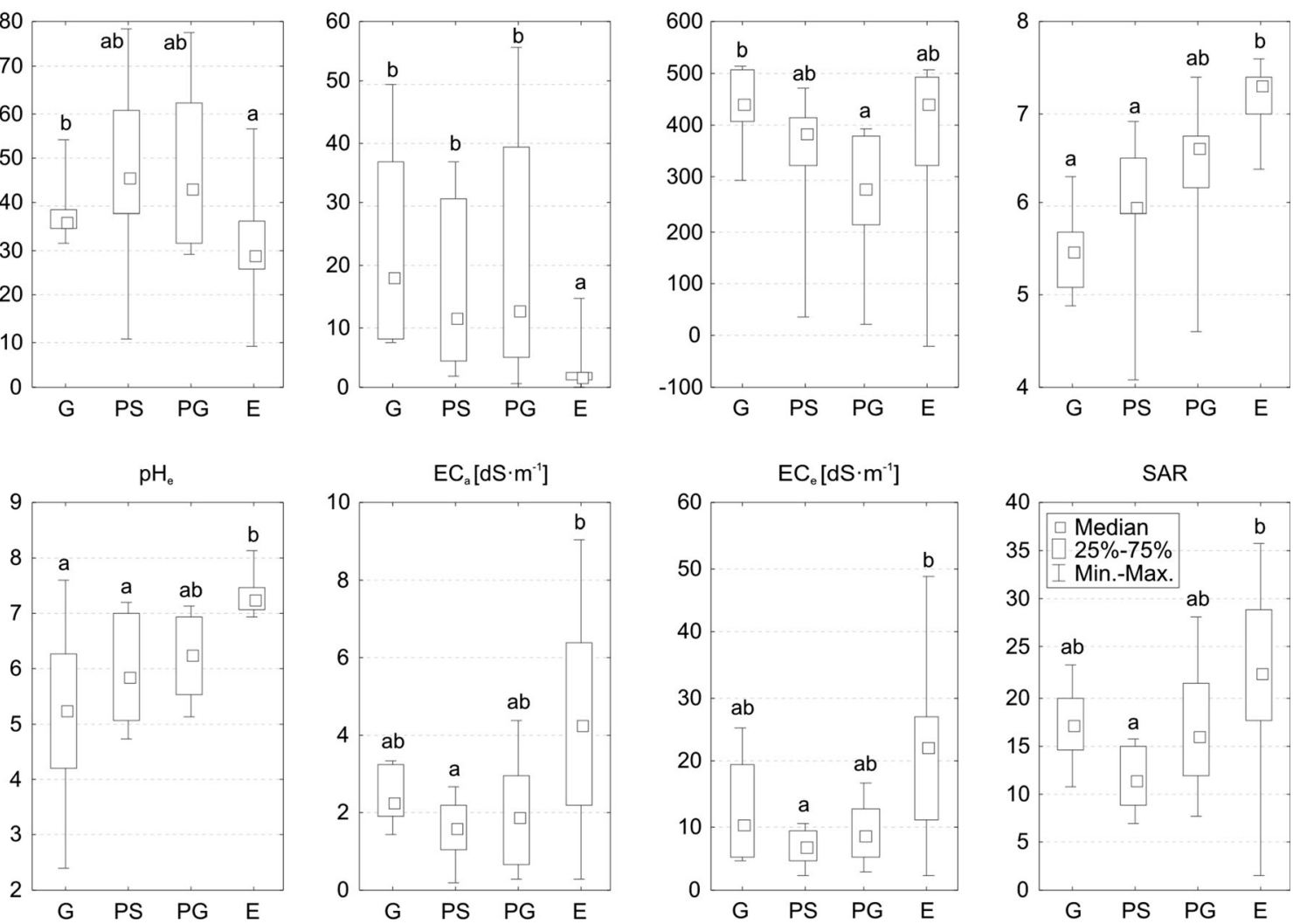

Fig. 2 Comparison of soil properties $(0-25 \mathrm{~cm})$ in four study areas. Kruskal-Wallis test was applied with Dunn test as post-hoc nonparametric multiple comparisons. Treatments with no difference are marked by the same letter (a or b). $\mathrm{M}$ - actual soil moisture, OM - organic matter

content, $\mathrm{E}_{\mathrm{h}}$ - redox potential, $\mathrm{pH}_{\mathrm{e}}-\mathrm{pH}$ of the soil saturated paste extract, $\mathrm{pH}_{\mathrm{a}}-$ actual $\mathrm{pH}$ measured in the field, $\mathrm{EC}_{\mathrm{a}}-$ electrical conductivity of the bulk soil, $\mathrm{EC}_{\mathrm{e}}-$ electrical conductivity of the soil saturated paste extract, SAR - sodium adsorption ratio. Study areas abbreviations as in Fig. 1

and $J$. gerardi were: Plantago maritima (33\%), Triglochin maritimum (26\%) and Bolboschoenus maritimus (21\%).

According to TWINSPAN classification, five groups of phytosociological relevés were distinguished: the Puccinellia maritima-Spergularia marina community, Juncus gerardi com., Agrostis stolonifera-Phragmites australis-Scirpus lacustris ssp. tabernaemontani com., Phragmites australis-Calystegia sepium com. and Elymus repens com. (Fig. 3).

The Puccinellia maritima-Spergularia marina com. Was typical for the first vegetation zone close to the waterline, and was noted on the Estonian (Kassari Island, Põgari-Sassi) and German (Kooser Wiesen) coasts. It was characterised by a low number of species and relatively low total species cover. However, on the Estonian coast Salicornia europaea and Suaeda maritima frequently accompanied two main species, i.e. P. maritima and S. marina.

Patches of Juncus gerardi com. were present in all investigated sites as salt meadows. They were characterised by relatively high cover of $J$. gerardi and the presence of other halophytic species, such as: Glaux maritima, Triglochin maritimum, Puccinellia maritima, Spergularia marina, Plantago maritima and Aster tripolium.

The next vegetation cluster, i.e. Agrostis stoloniferaPhragmites australis-Scirpus lacustris ssp. tabernaemontani com., covered vegetation patches of wet subhalophilous meadows with relatively high abundance of grasses, such as Agrostis stolonifera and Festuca rubra, and reed species, such as Scirpus lacustris ssp. tabernaemontani, Bolboschoenus maritimus and Phragmites australis. Single halophytes were noted in the relevés (Fig. 3) on the Polish and Estonian (Paljassaare) coasts.

Phragmites australis-Calystegia sepium com. was typical for the Polish coast, and was present in all investigated stands next to pioneer vegetation zones directly affected by waves. It was characterised by dominance of Phragmites australis accompanied by Calystegia sepium, Symphytum officinale, Phalaris arundinacea, Filipendula ulmaria and halophilous Atriplex hastata var. salina.

Elymus repens com. with dominant Elymus repens, Calamagrostis epigejos and Juncus effusus was represented by only one relevé, taken behind the small dike on the Karsiborska Kępa Island (Szczecin Lagoon). 
Fig. 3 Results of TWINSPAN classification of recorded relevés on German (G), Polish (PS and PG) and Estonian (E) coasts. Vegetation cluster abbreviations: Er-Elymus repens community, $\mathrm{Ph}-\mathrm{Cs}$ - Phragmites australisCalystegia sepium com., As-PhSt - Agrostis stoloniferaPhragmites australis-Scirpus lacustris ssp. tabernaemontani com., Jg - Juncus gerardi com., $\mathrm{Pm}-\mathrm{Sm}$ - Puccinellia maritimaSpergularia marina com. The cover of species transformed from Braun-Blanquet scale into ordinal scale. Rare species with one occurrence are omitted

\begin{tabular}{|c|c|c|c|c|c|}
\hline Sample name & $\begin{array}{l}P \\
S \\
1 \\
1 \\
\end{array}$ & $\begin{array}{l}\text { PPPPPPPPPP } \\
\text { GGSSSSSSSS } \\
4818181167 \\
\ldots 5.0 .34 \ldots\end{array}$ & $\begin{array}{l}\text { PPPPPPEE } \\
\text { SGGSSG91 } \\
365211.0 \\
\ldots .2 \ldots \\
\end{array}$ & $\begin{array}{l}\text { PEEGGPPPGPPG } \\
\text { s7542GGG6SS } 1 \\
1 \ldots \ldots 723.54 \text {. } \\
\ldots \ldots \ldots \ldots .\end{array}$ & $\begin{array}{l}\text { EEEGGEEE } \\
61335824 \\
\ldots \ldots \ldots \\
\ldots \ldots \ldots\end{array}$ \\
\hline Vegetation cluster & Er & $\mathrm{Ph}-\mathrm{Cs}$ & As-Ph-St & $\mathrm{Jg}$ & $\mathrm{Pm}-\mathrm{Sm}$ \\
\hline Juncus effusus & 5 & $----2-----$ & -------- & $2----------$ & -------1 \\
\hline Phragmites australis & - & -799999958 & $3--75723$ & $--3---------$ & ------ \\
\hline Calamagrostis epigejos & 5 & $----2---2-$ & -------- & ------------ & ------ \\
\hline Calystegia sepium & - & $-3233-3-35$ & $2-------$ & ------------ & ------ \\
\hline Carex gracilis & - & $--2------3$ & -------- & ------------ & ------- \\
\hline Cirsium arvense & - & $-3---2----$ & -------- & ------------ & ------- \\
\hline Epilobium tetragonum & - & $----32----$ & -------- & ------------ & ----- \\
\hline Filipendula ulmaria & - & $----3---57$ & $2------$ & ------------ & ---- \\
\hline Holcus lanatus & - & $----2---3-$ & -------- & ------------ & ----- \\
\hline Lycopus europae & - & $----2--2--$ & -------1 & ------------ & ---- \\
\hline Phalaris arund & - & $--2-25----$ & -------- & ------------ & ---- \\
\hline Rumex hydrolap & - & $--2----2--$ & -------- & ------------ & ------ \\
\hline chys palus & - & $--2-----22$ & -------- & ------------ & ------ \\
\hline Symphytum offi & - & $---2252--2$ & -------- & ------- & ---- \\
\hline Urtica dioica & - & $---23-3---$ & -------1 & ------------ & \\
\hline Deschampsia ces & - & --------73 & -------- & ---- & ---- \\
\hline Epilobium hirs & - & $--------2-$ & -------2 & ---- & ---- \\
\hline Lysimachia vulgo & - & $-3------32$ & -------- & ----- & ---- \\
\hline tha arvensis & - & --------33 & $2-------$ & ---- & ---- \\
\hline chus arven & - & $2-------22$ & -------- & ------------ & ------ \\
\hline Hydrocotyle vu & - & $--------2-$ & $3-------$ & --- & \\
\hline Rumex crispus & - & $2------1--$ & $2-------$ & --- & \\
\hline Eleocharis uni & - & ---------- & $---57---$ & --- & - \\
\hline Juncus articul & - & ---- & $3--8----$ & & \\
\hline Ranunculus rep & - & $--------2-$ & $2---2---$ & -- & \\
\hline rpus lacus & & & & & \\
\hline - tabernae & - & $2---------$ & $-5-8-522$ & & \\
\hline xacum off & - & ---------- & $2---2---$ & ------ & ---- \\
\hline Juncus ranarius & - & ------- & $3------7$ & & \\
\hline Lotus tenuis & - & ---------- & $5-------$ & $----2-------$ & --- \\
\hline Bolboschoenus m & - & $5-5-------$ & $-52---2-$ & $-------52---$ & $----2-$ \\
\hline Festuca arundir & - & $98--------$ & -------- & $------3-2--7$ & ------- \\
\hline entilla ans & - & $233-----22$ & $255-2---$ & $-3---5-22---$ & ------- \\
\hline folium repe & - & ---------- & $5------$ & $2---2-------$ & ------ \\
\hline Agrostis stolo & - & $--5-2--252$ & 35938837 & $8577875-525-$ & $-57---$ \\
\hline Elymus repens & 9 & ---------- & $--2-5---$ & $32--2---5--5$ & ----- \\
\hline Festuca rubra & - & $-----2--78$ & $795-----$ & $55-535-79---$ & ------ \\
\hline Poa pratensis & - & $--------5-$ & -------- & $-------5----$ & ------- \\
\hline $\begin{array}{l}\text { Alopecurus geniculatus } \\
\text { Atriplex hastata }\end{array}$ & - & ---------- & $----7---$ & $3--------53-$ & ------ \\
\hline - salina & - & $2--2222323$ & $3------$ & $222222-22357$ & $----2-$ \\
\hline Leontodon autu & - & ---------- & $2-2-----$ & $122---------$ & -- \\
\hline Poa subcaerulea & - & ---------- & $3------$ & $5-----------$ & ----- \\
\hline Aster tripoliu & - & ---------- & $-----5--$ & $-2---128----$ & ----- \\
\hline Ranunculus sce & - & ---------- & -------2 & $---------23-$ & ------ \\
\hline Trifolium fragiferum & - & ------ & $2-------$ & $-2--22------$ & ----- \\
\hline Polygonum aviculare & - & ---------- & -------- & $---2-------3$ & ------ \\
\hline Ranunculus trichophyllus & - & ---------- & -------- & $---------32-$ & ------ \\
\hline Odontites littc & - & ---------- & -------- & $-21---------$ & ----- \\
\hline cinellia di & - & ---------- & -------- & $------55----$ & ------- \\
\hline Triglochin maritima & - & ---------- & $---3----$ & $2225727-----$ & $-22----$ \\
\hline Glaux maritima & - & ---------- & $33------$ & $-772-253----$ & $32327--$ \\
\hline Juncus gerardi & - & ---------- & -------- & $-7575-87352-$ & $-372223-$ \\
\hline Plantago intermedia & - & ---------- & -------- & $------22----$ & $----2--$ \\
\hline Plantago maritima & - & --- & $5------2$ & $-8533222----$ & $273--2-$ \\
\hline
\end{tabular}

\section{Factors Responsible for Vegetation Differentiation}

Results of CCA analysis revealed that among the measured environmental variables, only $\mathrm{OM}, \mathrm{pH}_{\mathrm{e}}$ and $\mathrm{P}_{\mathrm{es}}$ were not significant in the species distribution pattern (Table 2). Because many factors were correlated with each other, conditional effects were analysed. It was discovered that salinity (expressed as $\mathrm{EC}_{\mathrm{e}}$ ), management type (hay/pasture vs. not used), redox potential, actual moisture and $\mathrm{pH}_{\mathrm{a}}$ were the most important (Table 2). These significant factors all together accounted for ca $24 \%$ of the total species variance. Salinity accounted for the highest amount of variance, i.e. $6.9 \%$, then management type $(5.3 \%)$, followed by $\mathrm{E}_{\mathrm{h}}(4.6 \%), \mathrm{M}$ $(3.6 \%)$ and $\mathrm{pH}_{\mathrm{a}}(3.4 \%)$.

The most saline places were occupied by Puccinellia maritima-Spergularia marina com. (Fig. 4). Next in the salinity gradient were Juncus gerardi com., Agrostis stoloniferaPhragmites australis-Scirpus lacustris ssp. tabernaemontani com. and Phragmites australis-Calystegia sepium com. Elymus repens com. was not separated on the ordination diagram and was located among patches of $\mathrm{Ag}-\mathrm{Ph}$-St com.

The management type gradient was of the same direction as the salinity gradient. All patches classified as $\mathrm{Pm}-\mathrm{Sm}$ com. 
Table 2 Results of forward selection, Monte Carlo permutation test and percent of species variance explained by each environmental factor. Significant factors are in bold. Simple term effect - independent effect of each factor, conditional effect - dependent effect of stepwise selected factors

\begin{tabular}{|c|c|c|c|c|c|c|c|}
\hline \multicolumn{3}{|c|}{ Simple term effects: } & \multirow[b]{2}{*}{$\mathrm{p}$} & \multicolumn{3}{|c|}{ Conditional term effects: } & \multirow[b]{2}{*}{$\mathrm{p}$} \\
\hline & $\%$ variance & pseudo-F & & & $\%$ variance & pseudo-F & \\
\hline $\mathbf{E C}_{\mathbf{e}}$ & 6.9 & 2.7 & 0.002 & $\mathbf{E C}_{\mathrm{e}}$ & 6.9 & 2.7 & 0.002 \\
\hline $\mathbf{P}_{\text {ew }}$ & 6.9 & 2.7 & 0.002 & hay/pasture & 5.3 & 2.2 & 0.002 \\
\hline $\mathrm{Cl}^{-}$ & 6.9 & 2.7 & 0.002 & $\mathbf{E}_{\mathbf{h}}$ & 4.6 & 1.9 & 0.002 \\
\hline hay/pasture & 6.9 & 2.7 & 0.002 & $\mathbf{M}$ & 3.6 & 1.5 & 0.022 \\
\hline not used & 6.9 & 2.7 & 0.002 & $\mathbf{p H}_{\mathbf{a}}$ & 3.4 & 1.5 & 0.020 \\
\hline $\mathrm{Na}^{+}$ & 6.7 & 2.7 & 0.002 & $\mathrm{Ca}^{2+}$ & 2.8 & 1.2 & 0.146 \\
\hline SAR & 6.6 & 2.6 & 0.002 & $\mathrm{EC}_{\mathrm{a}}$ & 2.7 & 1.2 & 0.164 \\
\hline $\mathbf{E C}_{\mathbf{a}}$ & 5.8 & 2.3 & 0.002 & $\mathrm{OM}$ & 2.7 & 1.2 & 0.198 \\
\hline $\mathrm{Ca}^{2+}$ & 5.5 & 2.2 & 0.002 & $\mathrm{pH}_{\mathrm{e}}$ & 2.3 & 1.0 & 0.442 \\
\hline $\mathbf{E}_{\mathbf{h}}$ & 5.3 & 2.1 & 0.002 & $\mathrm{Na}^{+}$ & 2.1 & 0.9 & 0.576 \\
\hline $\mathbf{M g}^{2+}$ & 4.7 & 1.8 & 0.028 & $\mathrm{P}_{\mathrm{es}}$ & 1.8 & 0.8 & 0.712 \\
\hline $\mathbf{M}$ & 3.8 & 1.5 & 0.022 & TDS & 1.9 & 0.8 & 0.708 \\
\hline $\mathbf{p H}_{\mathrm{a}}$ & 3.8 & 1.5 & 0.016 & $\mathrm{Mg}^{2+}$ & 1.2 & 0.5 & 0.986 \\
\hline $\mathrm{P}_{\mathrm{es}}$ & 3.4 & 1.3 & 0.100 & & & & \\
\hline OM & 2.9 & 1.1 & 0.302 & & & & \\
\hline $\mathrm{pH}_{\mathrm{e}}$ & 2.5 & 1.0 & 0.524 & & & & \\
\hline
\end{tabular}

and $J g$ com. were used as hay meadows or pastures, compared with ca. $40 \%$ of $A g-P h-S t$ com. and only $20 \%$ of $P h-C s$ com. (Table 3). Simple term effects comparison demonstrated that

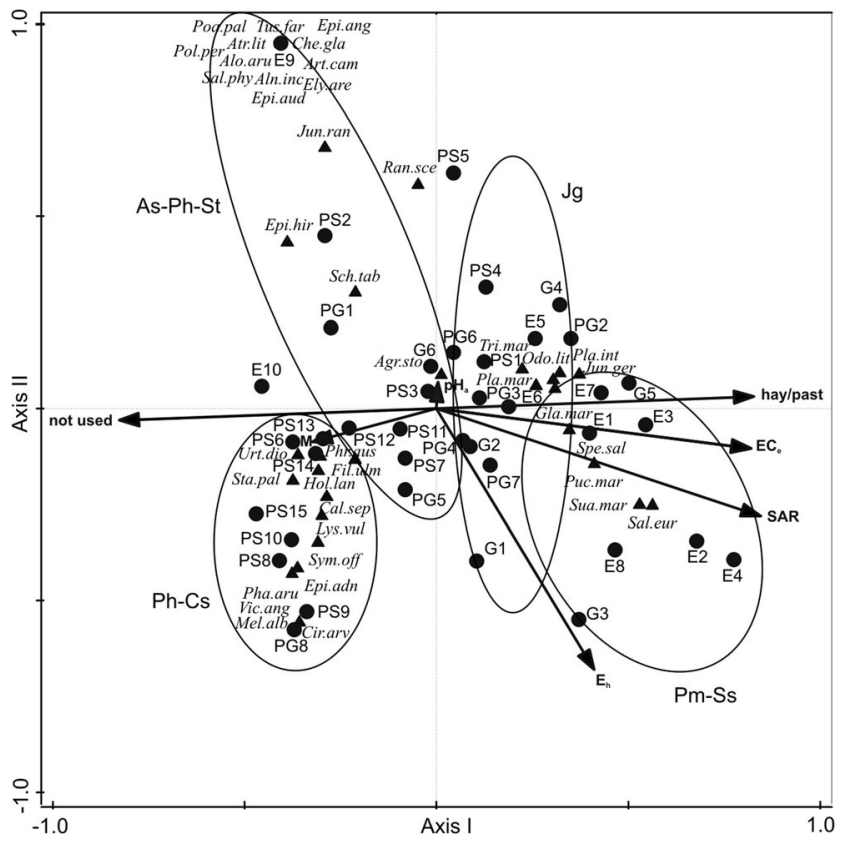

Fig. 4 CCA ordination diagram of the Baltic seashore vegetation showing correlation between typical species (of over $10 \%$ of fit into ordination space) and significant environmental variables $(p<0.05)$. $\mathrm{EC}_{\mathrm{e}}$ - electrical conductivity of the soil saturated paste extract. SAR sodium adsorption ratio, $\mathrm{E}_{\mathrm{h}}$ - redox potential, $\mathrm{M}$ - actual soil moisture, $\mathrm{pH}_{\mathrm{a}}-$ actual $\mathrm{pH}$, hay/pasture - hay or pasture lands, not used - abandoned places. Species abbreviations cover three letters of genus name and three letters of species name. Full species names and names of circled vegetation clusters as in Fig. 3 management type was significantly different for patches of $\mathrm{Ph}-\mathrm{Cs}$ com. and Pm-Sm com. and $\mathrm{Jg}$ com.

Soil properties (mean \pm SD) and management type in the distinguished vegetation clusters together with Kruskal-Wallis statistical comparisons with Dunne post-hoc test have been listed in Table 3.

\section{Discussion}

There were only small differences in the coastal water salinity within the analysed fragments of the coastal zone in the territory of Germany, Poland and Estonia - Table 1. Therefore, the obtained results can be considered as inconsistent with the spatial gradient of salinity of the Baltic Sea water (Majewski and Lauer 1994). This can probably be explained by specific, local environmental conditions in the coastal zones, especially the limited exchange of waters, the occurrence of the shallow lagoons and the riverine inflow (Hulisz 2013).

The significant impact of local factors on the soil environment in the area of the southern and eastern Baltic Sea coast was strongly confirmed by the results of the Kruskal-Wallis test with post-hoc mean rank multiple comparison (Fig. 2). The obtained data proved the statistical significance of the selected soil parameters in the differentiation of the study areas, which did not correspond to their location in the salinity gradient of the Baltic Sea open surface waters (nor to coastal water properties - Table 1). Characteristics related to salinity $\left(\mathrm{EC}_{\mathrm{a}}, \mathrm{EC}_{\mathrm{e}}\right.$ and $\left.\mathrm{SAR}\right)$ were one of the most important criteria differentiating the soils at sites located in the four Baltic Sea regions in Germany $(\mathrm{G})$, Poland (PS, PG) and Estonia (E). In 
Table 3 Soil properties (mean \pm SD) and management type in the distinguished vegetation clusters. The Kruskal-Wallis test with Dunne post-hoc multiple comparison between groups were applied.
Significantly different means are marked by different letters. Community abbreviations as in Fig. 3. ns - not significant

\begin{tabular}{|c|c|c|c|c|c|c|}
\hline & $\mathrm{Er}$ & $\mathrm{Ph}-\mathrm{Cs}$ & $\mathrm{As}-\mathrm{Ph}-\mathrm{St}$ & $\mathrm{Jg}$ & Pm-Sm & $\mathrm{p}$ \\
\hline $\mathrm{EC}_{\mathrm{a}}\left[\mathrm{dS} \cdot \mathrm{m}^{-1}\right]$ & 0.2 & $1.5 \pm 0.7$ & $1.3 \pm 0.7$ & $3.0 \pm 1.2$ & $4.6 \pm 2.8$ & ns \\
\hline $\mathrm{EC}_{\mathrm{e}}\left[\mathrm{dS} \cdot \mathrm{m}^{-1}\right]$ & 10.1 & $5.6^{\mathrm{a}} \pm 2.5$ & $6.5^{\mathrm{a}} \pm 4.2$ & $10.1^{\mathrm{ab}} \pm 4.7$ & $27.5^{\mathrm{b}} \pm 10.5$ & 0.0001 \\
\hline $\mathrm{P}_{\mathrm{es}}[\%]$ & 0.4 & $0.3 \pm 0.3$ & $0.5 \pm 0.9$ & $0.7 \pm 0.5$ & $0.8 \pm 0.7$ & ns \\
\hline $\mathrm{Na}^{+}\left[\mathrm{mg} \cdot \mathrm{dm}^{-3}\right]$ & 1422 & $861^{\mathrm{a}} \pm 518$ & $914^{\mathrm{a}} \pm 656$ & $1634^{\mathrm{ab}} \pm 692$ & $4731^{b} \pm 2680$ & 0.0001 \\
\hline $\mathrm{Mg}^{2+}\left[\mathrm{mg} \cdot \mathrm{dm}^{-3}\right]$ & 264 & $158^{\mathrm{a}} \pm 92$ & $254^{\mathrm{a}} \pm 279$ & $281^{\mathrm{a}} \pm 170$ & $1425^{\mathrm{b}} \pm 1542$ & 0.0005 \\
\hline $\mathrm{Ca}^{2+}\left[\mathrm{mg} \cdot \mathrm{dm}^{-3}\right]$ & 335 & $164^{\mathrm{a}} \pm 99$ & $209^{\mathrm{a}} \pm 131$ & $221^{\mathrm{a}} \pm 130$ & $516^{\mathrm{b}} \pm 154$ & 0.0028 \\
\hline SAR & 14 & $12^{\mathrm{ac}} \pm 4.6$ & $10^{\mathrm{a}} \pm 4.2$ & $18^{\mathrm{bc}} \pm 4.9$ & $25^{\mathrm{b}} \pm 6.8$ & 0.0002 \\
\hline $\mathrm{pH}_{\mathrm{a}}$ & 4.7 & $6.4^{\mathrm{ab}} \pm 0.4$ & $6.5^{\mathrm{ab}} \pm 0.6$ & $5.7^{\mathrm{a}} \pm 1.0$ & $7.0^{\mathrm{b}} \pm 0.6$ & 0.02 \\
\hline $\mathrm{pH}_{\mathrm{e}}$ & 4.9 & $6.5 \pm 0.8$ & $6.4 \pm 0.9$ & $5.9 \pm 1.0$ & $6.4 \pm 2.0$ & ns \\
\hline $\mathrm{E}_{\mathrm{h}}[\mathrm{mV}]$ & 375 & $373^{\mathrm{ab}} \pm 60$ & $176^{\mathrm{a}} \pm 167$ & $381^{\mathrm{ab}} \pm 114$ & $458^{b} \pm 66$ & 0.0026 \\
\hline $\mathrm{OM}[\%]$ & 11.0 & $14.5 \pm 14$ & $14.0 \pm 18$ & $18.5 \pm 15$ & $12.5 \pm 20$ & ns \\
\hline $\mathrm{M}[\%]$ & 16.0 & $53.1 \pm 18$ & $43.2 \pm 16$ & $41.3 \pm 17$ & $31.9 \pm 14$ & ns \\
\hline Hay/pasture [\% of patches] & - & $20^{\mathrm{a}}$ & $40^{\mathrm{ab}}$ & $100^{\mathrm{b}}$ & $100^{\mathrm{b}}$ & 0.0001 \\
\hline
\end{tabular}

addition, the unique combination of environmental factors in the Estonian coastal zone may contribute to very high soil salinity $\left(\mathrm{EC}_{\mathrm{e}}>30 \mathrm{dS} \cdot \mathrm{m}^{1}\right)$ and sodicity $(\mathrm{SAR}>20)$. The coastal flat plains in this region are developed from marine sediments overlaying glacial tills, which are a barrier to the vertical infiltration of saline water (Kalm and Kadastik 2001). In some cases, their long-term stagnation on poorly permeable layers and intensive evaporation, mostly during the summer season, can cause a very high increase in the salt concentration (EC up to $76 \mathrm{dS} \cdot \mathrm{m}^{-1}$ ) (Hulisz et al. 2011). Taking into account the brackish character of the Baltic sea waters, that phenomenon should be considered as very rare and untypical.

Single relevés of vegetation patches in the direct ordination results (Fig. 4) were not exactly located according to the averaged soil properties of investigated Baltic regions. That is to say, halophyte occurrence and the distribution of distinguished plant communities more closely reflected soil properties within the regions (on a local scale). As stated by Hulisz (2013), some soils directly affected by seawater may present a very specific spatial distribution pattern, where salinity increases with distance from the waterline (up to $100 \mathrm{~m}$ ). This can be explained by small-scale morphological diversity and other soil properties. A similar spatial heterogenity of local environmental conditions reflected by halophilous vegetation can be also found in Polish inland areas (Piernik et al. 2015).

The parameters responsible for vegetation pattern were $\mathrm{EC}_{\mathrm{e}}, \mathrm{E}_{\mathrm{h}}, \mathrm{M}$ and $\mathrm{pH}_{\mathrm{a}}-$ Fig. 4. Soil salinity has already been reported as the principle decisive factor for vegetation pattern from other salt marsh areas in the world (Chapman 1960; Adam 1990; Ortiz et al. 1995; Wanner 2009). The second important factor besides salinity was the management type of the studied sites. Some research has demonstrated, however, that management type can be even more important than salinity in influencing vegetation patterns (Amiaud et al. 1998; Jutila 2001; Piernik 2012). Moreover, the vegetation pattern can be affected in a different way by different intensities of cutting and grazing (Bakker 1989; Kiehl et al. 1996). We investigated relatively small areas directly affected by salt/ brackish water and, there, it was difficult to determine if the area is permanently mown or grazed (sometimes both). To obtain and assess the general pattern of investigated vegetation, we decided to distinguish only two categories of management, as is mentioned in the section Methods. In the case of our research, salinity and intensity of land use were in the same direction (Fig. 4), which is to say that the most saline places in the investigated gradient were managed. The third factor - redox potential - was related to the actual water table and its low values indicate anoxic conditions that can limit some species' occurrence. In tidal marshes, species have to face such conditions much more frequently than at the Baltic Sea coast (Adam 1990), but even on the Baltic Sea this factor is important. The last variables, i.e. actual moisture and $\mathrm{pH}$, are known to be important for halophytic species distribution (Piernik 2005; Wanner 2009; Bosiacka et al. 2011). What is quite surprising is that we did not detect any influence of organic matter content on vegetation distribution. This factor has been reported by many authors as important for halophytic vegetation because organic matter and nitrogen content can increase species' salt tolerance (Kiehl et al. 1997; Liu et al. 2004). At the same time, organic matter is responsible for many other properties of saline soils (Hulisz et al. 2013; Hulisz 2016). The obtained results suggest that, in the investigated seashore zone, which was directly related to the influence of water, organic matter did not affect general species pattern. 
We related the general vegetation pattern to the abiotic condition. However, there are many studies, especially in coastal tidal marshes, that stress the following biotic factors as important: competition (Snow and Vince 1984; Bertness 1991; Pennings and Callaway 1992; Ungar 1998; Egan and Ungar 2001), impact of parasites (Pennings and Callaway 1996) and herbivores (Miller et al. 1996), and the presence of mycorrhizae (Neto et al. 2006). These influence the general pattern and can modify the vegetation pattern on a local scale.

The distribution of species along the salinity gradient as we have described (Fig. 4) reflected a pattern known already from coastal and inland saline areas in Europe, with Salicornia europaea in the most saline places, followed by Suaeda maritima, Atriplex pedunculata, Puccinellia maritima and Spergularia marina, then Juncus gerardi, Plantago maritima, Aster tripolium, Atriplex hastata var. salina, and reed beds species Scirpus lacustris ssp. tabernaemontani, Eleocharis uniglumis, Bolboschoenus maritimus and Phragmites australis (Chapman 1960; Adam 1990; Nienartowicz and WilkońMichalska 1993; Piernik 2005). The gradient of land-use intensity demonstrates the presence of dominant Phragmites australis in unmanaged places, and species typical of salt meadows (dominated by Juncus gerardi) in patches used as pastures or hay meadows. Phragmites australis is a saltresistant species that can grow in extremely saline sites (Mauchamp and Mésleard 2001; Piernik 2012). Therefore, we relate its presence to management rather than salinity, although in our study, salinity and management were of the same direction (as explained above). A similar pattern to that of the Baltic Sea coast was described by Jutila (2001) and Wanner (2009).

Vegetation patches in the investigated sites were classified into five plant communities (Fig. 3). In managed places of the highest salinity $\left(\mathrm{EC}_{\mathrm{e}}\right.$, TDS, $\mathrm{Mg}^{2+}, \mathrm{Ca}^{2+}$ ) on the German and Estonian Baltic Sea coast, Puccinelia maritima-Spergullaria marina community was present (Table 3 ). This community has been described as typical for lower marshes on the Baltic coast (Dijkema 1990) and is present in lower marshes of the Wadden Sea (Bakker 1989). Second in the gradient of salinity was Juncus gerardi community, present on managed coastal meadows in all investigated areas. This vegetation type typically had significantly lower $\mathrm{pH}_{\mathrm{a}}$ than in patches of the previous community. Low $\mathrm{pH}_{\mathrm{a}}$ values can likely be explained by high levels of soil aeration and weak buffer capacity (lack of carbonates) favouring oxidation of sulphides (Hulisz 2013). This community is typical for middle marshes (Bakker 1989; Dijkema 1990).

The next two plant communities, i.e. Agrostis stoloniferaPhragmites australis-Scirpus lacustris ssp. tabernaemontani com. and Phragmites australis-Calystegia sepium com. Were found in places of significantly lower salinity compared to $\mathrm{Pm}$-Sm community. In general, they did not differ significantly in salinity level compared with $J g$ com. However, they cover mostly unmanaged patches. Therefore, they can be thought of as early and late successional stages, as described by Wanner (2009).

$A g-P h-S t$ com. in this case represented the early successional stage. Dijkema (1990) identified Agrostis stoloniferaJuncus gerardi community within lower marshes on the Baltic Northeaster Archipelagos. Therefore, this community could represent lower marsh vegetation, because it was characterised by a relatively lower salinity level and worse oxygen condition for vegetation.

$P h$-Cs community was typical for unmanaged, backwateraffected areas. Dijkema (1990) placed this type of vegetation as typical for emerging flats on the Baltic coast. The presence of Atriplex hastata var. salina indicated soil salinity in the vegetation patches (Piernik 2003), whereas Festuca arundinacea, Potentilla anserina, Agrostis stolonifera and Festuca rubra could be evidence of the potential grassland origin of these places. Therefore, they could represent the late successional stage, dominated by Phragmites australis after abandonment (Wanner 2009).

Only one relevé represented Elymus repens com. The communities with abundant Elymus species are more typical for upper coastal marshes (Bakker 1989) and for inland saline areas (Piernik 2012).

In conclusion, the spatial distribution of the investigated vegetation and soil properties along the southern and eastern Baltic seashore were inconsistent with the spatial salinity gradient of the open surface waters of the Baltic Sea. However, the obtained data proved the statistical significance of the selected soil parameters in the differentiation of the four study areas, which did not correspond to their geographical location. This is in contrast to our initial assumptions. Instead, vegetation pattern was dependent on the local environmental conditions. The main driving environmental factors for vegetation differentiation were: $\mathrm{EC}_{\mathrm{e}}$, management type, redox potential, actual moisture and $\mathrm{pH}_{\mathrm{a}}$. Results confirmed the key role of management for presence and structure of halophilous vegetation. Comparing the use of field and laboratory measurements for monitoring purposes, it seems appropriate to include those measured-in-field soil parameters which were significant for vegetation $\left(\mathrm{M}, \mathrm{E}_{\mathrm{h}}, \mathrm{pH}_{\mathrm{a}}\right)$, together with electrical conductivity of saturated paste extract $\left(\mathrm{EC}_{\mathrm{e}}\right)$ as a salinity measure.

Our results are important for understanding vegetationenvironment relationships on non-tidal salt marshes and for monitoring of these habitats. They are important for projects concerning landscape management strategy in coastal zones.

Acknowledgments The authors would like to thank Prof. Renata Bednarek, Prof. Urszula Pokojska, Prof. Luise Giani and Prof. Andrzej Nienartowicz for helpful comments on this work, to Dr. Mirosław T. Karasiewicz for his contribution in the fieldwork and Ms. Ewelina Urbańska, Mr. Adam Michalski and Mr. Michał Dabrowski for their assistance with laboratory analysis. This study was financed by the Polish Ministry of Science and Higher Education (grant N305 231135, 2008-2011). 
Open Access This article is distributed under the terms of the Creative Commons Attribution 4.0 International License (http:// creativecommons.org/licenses/by/4.0/), which permits unrestricted use, distribution, and reproduction in any medium, provided you give appropriate credit to the original author(s) and the source, provide a link to the Creative Commons license, and indicate if changes were made.

\section{References}

Adam P (1990) Saltmarsh ecology. Cambridge University Press, Cambridge

Amiaud B, Bouzille JB, Tournade F, Bonis A (1998) Spatial patterns of soils salinities in old embanked marshlands in western France. Wetlands 18:482-494

Bakker JP (1989) Nature management by grazing and cutting. Geobotanica 14. Kluwer Academic Publishers, Dordrecht

Bernhardt KG, Koch M (2003) Restoration of a salt marsh system: temporal change of plant species diversity and composition. Basic applied. Ecology 4:441-451

Bertness MD (1991) Interspecific interactions among high marsh perennials in a New England salt marsh. Ecology 72:125-137

Bosiacka B, Podlasiński M, Pieńkowski P (2011) Salt marshes determined by ascending brine in northern Poland: land-use changes and vegetation-environment relations. Phytocoenologia 41:201-213

Bosiacka B, Kull T, Więcław H, Marciniuk P, Podlasiński M (2016) Habitat requirements of marsh dandelions (Taraxacum sect. Palustria) in polish and Estonian coastal grasslands. Polish Journal of Ecology 64:481-498

Braun-Blanquet J (1964) Pflanzensoziologie, 3rd edn. Springer, Wien

Chapman VJ (1960) Salt marshes and salt deserts of the world. Leonard Hill Books Limited, London

Czyż H (ed) (2006) Salt grasslands and coastal meadows. AR Szczecin, Szczecin

Dijkema KS (1990) Salt and brackish marshes around the Baltic Sea and adjacent parts of the North Sea: their vegetation and management. Biological Conservation 51:191-209

Egan TP, Ungar IA (2001) Competition between Salicornia europaea and Atriplex prostrata (Chenopodiaceae) along an experimental salinity gradient. Wetlands Ecology and Management 9:457-461

Elvisto T (2010) Eutrophication level of Phragmites australis habitats at a shallow coastal lake, Paljassaare peninsula, Tallinn, Estonia. Estonian. Journal of Ecology 59:83-98

European Commission (1979) Council Directive 79/409/EEC on the conservation of wild birds

European Commission (1992) Council Directive 92/43/EEC of 21 May 1992 on the conservation of natural habitats and of wild fauna and flora. Official Journal L 206, 22/07/1992 P 0007-0050

Fock T, Hergarden K, Repasi D (eds) (2002) Salt grasslands and coastal meadows in the Baltic region. Fachhochschule Neubrandenburg, Neubrandenburg

Grube A (2000) Widespread geogenic salt water occurrence in North Germany. Proceedings of the 16th Salt Water Intrusion Meeting, Międzyzdroje-Wolin: 55-61

Hermanowicz W, Dojlido J, Dożańska W, Koziorowski B, Zerbe J (1999) Fizyczno-chemiczne analizy wody i ścieków. Wyd. Arkady, Warszawa

Hill MO (1979) TWINSPAN: A FORTRAN program for arranging Multivariate Data in order two-way table by classification of the individual and attributes. Cornell University, Ithaca, New York

Hill MO, Šmilauer P (2005) Twinspan for Windows 2.3. Centre for Ecology and Hydrology, University of South Bohemia, Hutington, Česke Budějovice
Hulisz P (2013) Geneza, właściwości i pozycja systematyczna marszy brakicznych w strefie oddziaływania wód Bałtyku. Nicolaus Copernicus University Press, Toruń

Hulisz P (2016) Coastal marsh soils in Poland: characteristics and problems of classification. Soil Science Annual 67:37-44

Hulisz P, Elvisto T, Karasiewicz MT, Piernik A (2011) Abiotic factors influencing the occurrence of Salicornia europaea in West Estonia. Ecological Questions 14:57-60

Hulisz P, Gonet SS, Giani L, Markiewicz M (2013) Chronosequential alterations in soil organic matter during initial development of coastal salt marsh soils at the southern North Sea. Zeitschrift für Geomorphologie 57:515-529

Jackson ML (1958) Soil chemical analysis. Constable Ldt, London

Jongman RHG, ter Braak CJF, van Tongeren DFR (eds) (1995) Data analysis in community and landscape ecology. Pudoc, Wageningen

Jutila H (2001) How does grazing by cattle modify the vegetation of coastal grasslands along the Baltic Sea? Annales Botanici Fennici 38:181-200

Kall T, Oja T, Tänavsuu K (2014) Postglacial land uplift in Estonia based on four precise levelings. Technophysics 610:25-38

Kalm V, Kadastik E (2001) Waterlain glacial diamicton along the Palivere ice-marginal zone on the west Estonian archipelago, eastern Baltic Sea. Proceedings of the Estonian. Academy of Sciences 50:114-127

Kiehl K, Eischeid I, Gettner S, Walter J (1996) Impact of different sheep grazing intensities on salt marsh vegetation in northern Germany. Journal of Vegetation Science 7:99-106

Kiehl K, Esselnik P, Bakker JP (1997) Nutrient limitation and plant species composition in temperate salt marshes. Oceanologia 111:325-330

Kottek M, Grieser J, Beck C, Rudolf B, Rubel F (2006) World map of the Köppen-Geiger climate classification updated. Meteorologische Zeitschrift 15:259-263

Lampe R, Janke W (2004) The Holocene sea level rise in the southern Baltic as reflected in coastal peat sequences. Polish Geological Institute Special Papers 11:19-30

Liu X, Yang Y, Li W, Li C, Duan D, Tadano T (2004) Interactive effects of sodium chloride and nitrogen on growth and ion accumulation of a halophyte. Communications in Soil Science and Plant Analysis 35: 2111-2123

Ludewig K, Wanner A, Jensen K (2015) Recolonization and facilitation in Baltic salt marsh vegetation. Annales Botanici Fennici 52:181-191

Majewski A, Lauer Z (eds) (1994) Atlas Morza Bałtyckiego. IMGW, Warszawa

Mauchamp A, Mésleard F (2001) Salt tolerance in Phragmites australis populations from coastal Mediterranean marshes. Aquatic Botany 70:39-52

Miller DL, Smeins FE, Webb JW (1996) Mid-Texas coastal marsh change (1939-1991) as influenced by lesser snow goose herbivory. Journal of Coastal Research 12:462-476

Moeslund JE, Arge L, Bøcher PK, Nygaard B, Svenning JC (2011) Geographically comprehensive assessment of salt-meadow vegetation-elevation relations using LiDAR. Wetlands 31:471-482

Morris JT, Sundareshwar PV, Nietch CT, Kjerfve B, Cahoon DR (2002) Responses of coastal wetlands to rising sea level. Ecology 83:2869-2877

Neto D, Carvalho LM, Cruz C, Martinez-Lucao MA (2006) How do mycorrhizas affect $\mathrm{C}$ and $\mathrm{N}$ relationships in flooded Aster tripolium plants. Plant and Soil 279:51-63

Nicholls RJ, Hoozemans FMJ, Marchand M (1999) Increasing flood risk and wetland losses due to global sea-level rise: regional and global analyses. Global Environmental Change 9, Suppl. 1:69-87

Niedermeyer RO, Scholle T, Flemming BW, Hertweck G (1995) Holocene sediments and basin development of a Pomeranian coastal lagoon (Greifswalder Bodden; Southern Baltic). Prace PIG 149:117-121

Nienartowicz A, Wilkoń-Michalska J (1993) The application of numerical analysis to comparison of ecological amplitudes of halophytic species. Variability and Evolution 2(3):103-112 
Ortiz R, Alvarez Rogel J, Alcaraz F (1995) Soil-vegetation relationships in two coastal salt marshes in southeastern Spain. Arid Soil Research and Rehabilitation 9:481-493

Pennings SC, Callaway RM (1992) Salt marsh plant zonation: the relative importance of competition and physical factors. Ecology 73:681-690

Pennings SC, Callaway RM (1996) Impact of a parasitic plant on the structure and dynamics of salt marsh vegetation. Ecology $77: 1410-1419$

Piernik A (2003) Inland halophilous vegetation as indicator of soil salinity. Basic applied. Ecology 4:525-536

Piernik A (2005) Vegetation-environment relations on inland saline habitats in Central Poland. Phytocoenologia 35:19-37

Piernik A (2012) Ecological pattern of inland salt marsh vegetation in Central Europe. Nicolaus Copernicus University Press, Toruń

Piernik A, Hulisz P, Rokicka A (2015) Micropattern of halophytic vegetation on technogenic soils affected by the soda industry. Soil Science \& Plant Nutrition 61:98-112

Piotrowska H (1974) Nadmorskie zespoły solniskowe w Polsce i problemy ich ochrony. Ochrona Przyrody 39:7-63

Pracz J (1989) Właściwości gleb tworzacych się przy udziale słonej wody gruntowej w polskiej strefie przybałtyckiej. SGGW-AR, Warszawa

Rannap R, Lõhmus A, Jakobson K (2007) Consequences of coastal meadow degradation: the case of the natterjack toad (Bufo calamita) in Estonia. Wetlands 27:390-398

Ratas U, Puurmann E, Pappel P (2006) Soils and water conditions in land uplift coastal areas of the Baltic Sea, Estonia. In: Czyż H (ed) Salt grassland and coastal meadows Wyd AR, Szczecin, pp 91-96

Rebassoo HE (1975) Sea-shore plant communities of the Estonian islands. Academy of Sciences of the Estonian SSR, Tartu
Snow AA, Vince SW (1984) Plant zonation in Alaskan salt-marsh. II. An experimental study of the role of edaphic conditions. Journal of Ecology 72:669-684

ter Braak CJF, Šmilauer P (2012) CANOCO Reference manual and User's guide: Software Ordination (version 5.0). Biometrics, Wageningen and České Budějowice

Tutin TG, Heywood VH, Moore DM, Valentine DH, Walters SM, Weeb DA (1964-1980) Flora Europaea, vol 1-5. Cambridge University Press, Cambridge

Ungar IA (1998) Are biotic factors significant in influencing the distribution of halophytes in saline habitats? The Botanical Review 64:176-199

van der Graaf AJ, Stahl J, Veeneklaas RM (2007) Vegetation characteristics of a brackish marsh on Gotland and foraging choices of migrating and brood rearing geese. Annales Botanici Fennici 44:33-41

van der Maarel E (1979) Transformation of cover-abundance values in phytosociology and its effect on community similarity. Vegetatio 39:97-114

van Reeuwijk LP (2006) Procedures for soil analysis. 7th ed. Technical Report 9. ISRIC - World Soil Information, Wageningen

Wanner A (2009) Management, biodiversity and restoration potential of salt grassland vegetation of the Baltic Sea: Analyses along a complex ecological gradient. $\mathrm{PhD}$ thesis, University of Hamburg, Hamburg

Westhoff V, van der Maarel E (1978) The Braun-Blanquet approach. In: Whittaker RH (ed). Classification of plant communities Junk, Thee Hague, pp 287-339

Zar JH (1999) Biostatistical analysis. Prentice-Hall, Englewood Cliffs 